\title{
The Impact of Antioxidant Addition on Flavor of Cheddar and Mozzarella Whey and Cheddar Whey Protein Concentrate
}

\author{
I.W. Liaw, H. Eshpari, P.S. Tong, and M.A. Drake
}

\begin{abstract}
Lipid oxidation products are primary contributors to whey ingredient off-flavors. The objectives of this study were to evaluate the impact of antioxidant addition in prevention of flavor deterioration of fluid whey and spray-dried whey protein. Cheddar and Mozzarella cheeses were manufactured in triplicate. Fresh whey was collected, pasteurized, and defatted by centrifugal separation. Subsequently, $0.05 \%(\mathrm{w} / \mathrm{w})$ ascorbic acid or $0.5 \%(\mathrm{w} / \mathrm{w})$ whey protein hydrolysate (WPH) were added to the pasteurized whey. A control with no antioxidant addition was also evaluated. Wheys were stored at $3{ }^{\circ} \mathrm{C}$ and evaluated after $0,2,4,6$, and $8 \mathrm{~d}$. In a subsequent experiment, selected treatments were then incorporated into liquid Cheddar whey and processed into whey protein concentrate (WPC). Whey and WPC flavors were documented by descriptive sensory analysis, and volatile components were evaluated by solid phase micro-extraction with gas chromatography mass spectrometry. Cardboard flavors increased in fluid wheys with storage. Liquid wheys with ascorbic acid or WPH had lower cardboard flavor across storage compared to control whey. Lipid oxidation products, hexanal, heptanal, octanal, and nonanal increased in liquid whey during storage, but liquid whey with added ascorbic acid or WPH had lower concentrations of these products compared to untreated controls. Mozzarella liquid whey had lower flavor intensities than Cheddar whey initially and after refrigerated storage. WPC with added ascorbic acid or WPH had lower cardboard flavor and lower concentrations of pentanal, heptanal, and nonanal compared to control WPC. These results suggest that addition of an antioxidant to liquid whey prior to further processing may be beneficial to flavor of spray-dried whey protein.
\end{abstract}

Practical Application: Lipid oxidation products are primary contributors to whey ingredient off-flavors. Flavor plays a critical and limiting role in widespread use of dried whey ingredients, and enhanced understanding of flavor and flavor formation as well as methods to control or minimize flavor formation during processing are industrially relevant. The results from this study suggest that addition of an antioxidant to liquid whey prior to further processing may be beneficial to minimize flavor of spray-dried whey protein.

\section{Introduction}

Dried whey ingredients are useful ingredients in food products because of their high solubility, dispersibility, water binding, foaming, whipping, emulsification, gelation, and buffering power (Bryant and McClements 1998; de Wit 1998; Foegeding and others 2002). Whey proteins have gained further popularity for health benefits including increasing colon health (McIntosh and others 1998), cardiovascular health (Mullally and others 1997), and athletic enhancement (Cornish and others 2009).

Flavor is generally recognized as the single most important factor affecting consumer acceptance of food products (Lee and Morr 1994; Drake 2006; Childs and Drake 2009). Dried whey ingre- dients ideally should have a bland, delicate flavor free from undesirable flavors (Morr and Ha 1993; Wright and others 2009). Off-flavors in whey products can carry through into ingredient applications (Drake and others 2009; Wright and others 2009), and may limit widespread use of these products (Quach and others 1999; Childs and others 2007).

Flavor variability has been identified in liquid whey and dried whey products both between and within manufacturers (Carunchia-Whetstine and others 2003, 2005; Drake and others 2009; Wright and others 2009). Flavor variability has been sourced to the liquid whey itself and is also an outcome of downstream processing and storage techniques (Carunchia-Whetstine and others 2003, 2005; Drake and others 2009). Different starter cultures in the cheese-making process are utilized to produce a variety of cheeses and the resulting liquid wheys have distinct mineral content, protein concentration, and lactose content, as well as distinct flavor properties (Bordenave-Juchereau and others 2005; Gallardo-Escamilla and others 2005).

Many studies have reported that flavor of whey and whey products changes during storage, light exposure, and added heat (Morr 
and Ha 1993; Lee and others 1995; Tomaino and others 2004; Wright and others 2009). Aldehydes, including hexanal, have been suggested as the compounds responsible for off-flavors in liquid and dried whey products (Quach and others 1999; Tomaino and others 2004; Wright and others 2009). In 2004, Tomaino and others observed lipid oxidation products in fresh fluid whey and increases in aldehyde concentrations concurrent with increased off-flavors during refrigerated storage of liquid whey. Lipid oxidation products were also prevalent in freshly manufactured whey proteins (Carunchia-Whetstine and others 2005; Evans and others 2009; Wright and others 2009) and concentrations increased with storage time concurrent with increased sensory-perceived off-flavors (Wright and others 2009). Collectively, these studies demonstrate that lipid oxidation products contribute to undesirable flavors in whey proteins.

The 2 main sources of liquid whey in the United States are derived from Cheddar and Mozzarella cheese production and these whey streams were the focus of the current study. The objectives of this study were to evaluate methods to minimize lipid oxidation in liquid whey and whey protein concentrate through the addition of antioxidants to liquid whey. Antioxidants were administered to freshly produced Cheddar and Mozzarella liquid whey to determine if antioxidant addition minimized off-flavor production in liquid whey. Ascorbic acid and whey protein hydrolysate were the antioxidants selected. Previous studies (Jung and others 1998; Lindmark-Månsson and Åkesson 2000; Tong and others 2000; Mortenson and others 2004; Hernandez-Ledesma and others 2005) have confirmed the antioxidative properties of these ingredients. Subsequently, selected treatments were evaluated in finished spray-dried whey protein concentrate (WPC) from Cheddar whey. Sensory and instrumental analyses were applied to document properties of liquid wheys and whey protein concentrates.

\section{Materials and Methods}

\section{Fluid whey manufacture}

Milk. Raw unhomogenized whole milk (NCSU Creamery, Raleigh, N.C., U.S.A.) for cheese production was high temperature short time (HTST) pasteurized with a plate heat exchanger (APV, APV Co. Ltd., Crawley, West Sussex, U.K.) at $75{ }^{\circ} \mathrm{C}$ and a holding time of $28 \mathrm{~s}$. The pasteurized milk was cooled to $3{ }^{\circ} \mathrm{C}$ and stored for less than $24 \mathrm{~h}$. The average fat and protein content of the milk were $3.62 \% \pm 0.10$ (CEM Smart Trac Rapid Fat Analysis, Matthews, N.C., U.S.A.) and 3.34\% \pm 0.08 (LactiCheck Milk Analyzer Dual Cow Channel LC-02, P\&P Intl. Ltd, Hopkinton, Mass., U.S.A.). During cheese manufacture, the $\mathrm{pH}$ of whey and cheese were measured with an electrode (Model IQ150, IQ Scientific Instruments, Inc., Loveland, Colo., U.S.A.) that was standardized at $\mathrm{pH}, 6.97$ and 4.03 at $38^{\circ} \mathrm{C}$ and kept immersed in $3 \mathrm{M} \mathrm{KCl}$ at $38^{\circ} \mathrm{C}$ between readings to keep its temperature equal to the temperature of the samples.

Cheddar cheese and Mozzarella wheys. Pasteurized milk $\left(3^{\circ} \mathrm{C}\right)$ was transferred into a cheese vat (Model 4MX, Kusel Equipment Co., Watertown, Wis., U.S.A.). For Cheddar whey, the temperature of the milk was raised to $31^{\circ} \mathrm{C}$ with gentle stirring. Once the milk reached $31{ }^{\circ} \mathrm{C}$, calcium chloride [0.0018M] (Dairy Connection Inc., Madison, Wis., U.S.A.) at a rate of $180 \mathrm{~mL} / 454 \mathrm{~kg}$ milk and annatto color (double strength, Dairy Connection Inc.) at a rate of $15 \mathrm{~mL} / 454 \mathrm{~kg}$ milk were added to the milk along with a freeze-dried starter culture of Lactococcus lactis ssp. lactis and Lactococcus lactis ssp. cremoris (Danisco Choozit, Dairy Con- nection Inc.) at the rate of $50 \mathrm{DCU} / 454 \mathrm{~kg}$ milk. (DCU is a unit of activity.) The milk was continuously stirred and allowed to ripen for $60 \mathrm{~min}$. The ripened milk, at $31^{\circ} \mathrm{C}$, was coagulated with double strength chymosin $(40 \mathrm{~mL} / 454 \mathrm{~kg}$ milk, Star Rennet Double Strength, Dairy Connection Inc.) for $30 \mathrm{~min}$ with no agitation and no heat. Firm coagulum was cut with $0.95 \mathrm{~cm}$ wire knives. Curds and whey were allowed to heal for $5 \mathrm{~min}$ and then were gently stirred for $10 \mathrm{~min}$ without added heat. The temperature was gradually increased from 31 to $39^{\circ} \mathrm{C}$ and continuously stirred over $30 \mathrm{~min}$ or until the target whey $\mathrm{pH}$ of 6.3 was attained. Cheese whey was immediately drained and pumped into a pasteurizer (Model MPD1050, D\&F Equipment Co., McLeansville, N.C., U.S.A.) and pasteurized at $65{ }^{\circ} \mathrm{C}$ for $30 \mathrm{~min}$ to inactivate the starter culture. Cheddar cheese whey was manufactured in triplicate.

For Mozzarella whey, the temperature of the pasteurized milk was raised to $35{ }^{\circ} \mathrm{C}$ with gentle stirring. Once the milk reached $35^{\circ} \mathrm{C}$, calcium chloride [180 mL/454 kg milk] (Dairy Connection, Inc.) and freeze-dried starter cultures were added. Streptococcus thermophilus $(50$ DCU/454 kg milk, Danisco Choozit, Dairy Connection, Inc.) and Lactobacillus delbrueckii ssp. lactis and Lactobacillus helveticus (20 DCU/454 kg milk, Danisco Choozit, Dairy Connection, Inc.) were added to the warmed milk. The milk was continuously stirred and allowed to ripen for $60 \mathrm{~min}$ at $35^{\circ} \mathrm{C}$. The ripened milk, at $35^{\circ} \mathrm{C}$, was coagulated with double strength chymosin (40 mL/454 kg milk, Dairy Connection Inc.) for $30 \mathrm{~min}$ with no agitation and no heat. Firm coagulum was cut with $0.95 \mathrm{~cm}$ wire knives. Curds and whey were allowed to heal for $5 \mathrm{~min}$ and then were gently stirred for $10 \mathrm{~min}$ without added heat. The temperature was gradually increased from 35 to $40{ }^{\circ} \mathrm{C}$ and continuously stirred over $30 \mathrm{~min}$ or until the target whey $\mathrm{pH}$ of 6.3 was attained. The whey was then drained and pasteurized at $65^{\circ} \mathrm{C}$ for $30 \mathrm{~min}$ to inactivate the starter cultures. Mozzarella cheese whey was manufactured in triplicate.

Liquid whey treatments. After pasteurization of Cheddar and Mozzarella liquid whey, $26 \mathrm{~L}$ of each liquid whey were collected, cooled in an ice bath to $10^{\circ} \mathrm{C}$, and designated as the fat control (C1). The remaining hot whey (104 L) was run through a separator (Clair Milky, FJ-125 EAP 115V nr 17584-115-3, Warenhandels $\mathrm{GmbH}$, Whitewater, Wis., U.S.A.) for fat separation. The fat content of the whey before and after separation was monitored (CEM Smart Trac Rapid Fat Analysis, Matthews). Separated whey was cooled to $10^{\circ} \mathrm{C}$ in an ice bath. This cooled whey was divided into 3 portions. Whey without added treatment was assigned as the separated fat control (C2). Treatment 1 consisted of the addition of $0.05 \%(\mathrm{w} / \mathrm{w})$ ascorbic acid (VWR Intl., West Chester, Pa., U.S.A.). Treatment 2 consisted of the addition of $0.5 \%(\mathrm{w} / \mathrm{w})$ whey protein hydrolysate (WPH) (type 8350, Hilmar Ingredients, Hilmar, Calif., U.S.A.) to the liquid whey. Each of these ingredients was incorporated into the cooled whey by gentle agitation with a wire whisk for 5 to $10 \mathrm{~min}$. Preliminary testing with cooled Cheddar whey confirmed that this method of incorporation fully dissolved the ingredients with no visible lumps or sediment. Samples were stored in $950 \mathrm{~mL}$ amber glass jars capped with PTFE faced PE-lined screw caps (Fisher Scientific, Hanover Park, Ill., U.S.A.) at $3{ }^{\circ} \mathrm{C}$ in the dark. Samples were held at $3{ }^{\circ} \mathrm{C}$ for $8 \mathrm{~d}$. Aliquots $(1.5 \mathrm{~L})$ were taken from each treatment and tested after $0,2,4,6$, and $8 \mathrm{~d}$ by descriptive sensory analysis and instrumental volatile analysis. Total solids of whey were evaluated by forced draft oven (AOAC Method 990.19) and protein by Kjeldahl analysis with a conversion factor of 6.38 . The $\mathrm{pH}$ of wheys was taken at each storage time point to confirm absence of microbial growth. 


\section{Descriptive sensory analysis}

Sensory testing was conducted in compliance with NCSU Institutional Review Board (IRB) for human subjects approval. A trained sensory panel $(n=10,7$ female, 3 male, ages 22 to $37 \mathrm{y})$ evaluated the flavor attributes of the liquid whey using a previously established lexicon for fluid whey (Carunchia-Whetstine and others 2003; Drake and others 2003; Drake and others 2009). Each panelist had over $150 \mathrm{~h}$ of experience with descriptive analysis of dried dairy ingredients, and additional training with liquid whey aroma and flavor. Consistent with Spectrum ${ }^{\mathrm{TM}}$ descriptive analysis training, panelists were presented with reference solutions of sweet, sour, salty, and bitter tastes to learn to use the universal intensity scale (Meilgaard and others 1999; Drake and Civille 2003). Panelists then evaluated and discussed flavor attributes of Cheddar and Mozzarella liquid whey with and without treatment addition. Analysis of variance of data collected in preliminary sessions confirmed that the panel and the panelists could consistently identify and scale flavor attributes. Attribute intensities were scaled using the 0 - to 15 -point universal intensity scale characterized by the Spectrum descriptive analysis method (Meilgaard and others 1999; Drake and Civille 2003).

Liquid wheys (approximately $30 \mathrm{~mL}$ ) were dispensed into lidded $58 \mathrm{~mL}$ soufflé cups with 3-digit codes. Products were tempered to $20^{\circ} \mathrm{C}$ and served at this temperature with spring water and unsalted crackers for palate cleansing. Panelists evaluated each sample individually in booths in a positive air pressure room dedicated to sensory analysis. Each product replication was evaluated by each panelist in duplicate in a randomized balanced block design on separate occasions. Products were scored using paper ballots or computerized ballots using Compusense ${ }^{\mathrm{TM}}$ five version 4.8 (Compusense, Guelph, ON, Canada).

\section{Solid phase microextraction gas chromatography mass spectrometry (SPME GC-MS)}

Volatile compounds of wheys were evaluated by SPME GCMS. SPME GC-MS was conducted using a modified method of Wright and others (2006). Five grams of liquid whey with $10 \%$ $\mathrm{NaCl}(\mathrm{w} / \mathrm{w})$ (VWR Intl.) and $10 \mu \mathrm{L}$ internal standard solution (2-methyl-3-heptanone in methanol at $8.1 \mathrm{ppm}$; Sigma-Aldrich, Milwaukee, Wis., U.S.A.; VWR Intl., West Chester, Pa., U.S.A.) were placed into $20 \mathrm{~mL}$ autosampler vials with steel screw tops containing silicone septa faced in teflon (Microliter Analytical, Sawanee, Fla., U.S.A.). Samples were injected using a CombiPal autosampler (CTC Analytics, Zwingen, Switzerland) attached to an Agilent 6890N GC with 5973 inert MSD (Agilent Technologies Inc., Santa Clara, Calif., U.S.A.). Samples were maintained at $5^{\circ} \mathrm{C}$ prior to fiber exposure. Samples were equilibrated at $40^{\circ} \mathrm{C}$ for $25 \mathrm{~min}$ before $30 \mathrm{~min}$ fiber exposure of a $1 \mathrm{~cm}$ DVB/CAR/PDMS fiber at $31 \mathrm{~mm}$ with $4 \mathrm{~s}$ pulsed agitation at $250 \mathrm{rpm}$. Fibers were injected for $5 \mathrm{~min}$ at a depth of $50 \mathrm{~mm}$. The GC method used an initial temperature of $40{ }^{\circ} \mathrm{C}$ for $3 \mathrm{~min}$ with a ramp rate of $10{ }^{\circ} \mathrm{C} / \mathrm{min}$ to $90^{\circ} \mathrm{C}$, increased at the rate of $5^{\circ} \mathrm{C} / \mathrm{min}$ to $200{ }^{\circ} \mathrm{C}$, held for $5 \mathrm{~min}$ and finally increased at a rate of $20^{\circ} \mathrm{C} / \mathrm{min}$ to $250{ }^{\circ} \mathrm{C}$ held for $5 \mathrm{~min}$. SPME fibers were introduced into the split/splitless injector at $250^{\circ} \mathrm{C}$ at pressure of 7.06 psi with helium carrier gas, with a purge flow of $1697.7 \mathrm{~cm} / \mathrm{s}$. An Rtx-5 ms column (Rtx-5 ms $30 \mathrm{~m}$ length $\times 0.25 \mathrm{~mm}$ inner dia $\times 0.25 \mathrm{um}$ film thickness; Restek, Bellefonte, Pa., U.S.A.) was used for all analyses at a constant flow rate of $34 \mathrm{~cm} / \mathrm{s}$. Purge time was set at $1 \mathrm{~min}$. The MS transfer line was maintained at $250{ }^{\circ} \mathrm{C}$ with the Quad at $150^{\circ} \mathrm{C}$ and Source at $250^{\circ} \mathrm{C}$. Compounds were identified using the NIST 2005 library of spectra and comparison of spectra of authentic standards injected under identical conditions. Relative abundance for each compound was calculated using the recovery of the internal standard concentration to determine relative abundance of each compound. Retention indices were calculated using an alkane series (Sigma-Aldrich) (Van den Dool and Kratz 1963). Each sample was injected in triplicate for each treatment replication.

\section{Whey protein concentrate manufacture}

Raw milk was obtained from the Cal Poly Dairy (San Luis Obispo, Calif., U.S.A.), pasteurized and used for Cheddar WPC production with the same cheese make procedure as previously described for Cheddar liquid whey production. Fresh liquid whey was collected, pasteurized $\left(71.7^{\circ} \mathrm{C}\right.$ for $\left.16 \mathrm{~s}\right)$, fat separated (AlfaLaval, Richmond, Va., U.S.A.), and cooled. In separate batches, ascorbic acid and WPH $(0.05 \%$ [w/w] ascorbic acid, $0.5 \%$ [w/w] $\mathrm{WPH}$ ) treatments were incorporated into the cooled liquid whey as previously described. A control of fat separated liquid whey was also produced, receiving no treatments. Whey treatments and control were stored overnight at $4{ }^{\circ} \mathrm{C}$ for further processing the next day.

Before WPC processing, ultrafiltration membranes were cleaned according to a standard washing procedure. First, an alkaline wash with sodium hydroxide $\left(45 \mathrm{~min}, 50^{\circ} \mathrm{C}, \mathrm{pH} 12\right)$ was administered followed by rinsing with deionized water $\left(30 \mathrm{~min}, 50^{\circ} \mathrm{C}\right)$. Then an acid wash with phosphoric and nitric acids $\left(15 \mathrm{~min}, 45^{\circ} \mathrm{C}, \mathrm{pH}\right.$ 2) was administered, followed by a final membrane reconditioning with deionized water. Liquid wheys were ultrafiltrated (UF), followed by diafiltration (DF) and spray drying. Filtrations were carried out continuously $\left(10^{\circ} \mathrm{C}, 517.107 \mathrm{kPa}, 4.456 \times 10^{-3} \mathrm{cu} . \mathrm{ft} / \mathrm{s}\right)$ through a Niro R-12 Universal Membrane System (Niro Inc., Hudson, Wis., U.S.A.) equipped with a polymeric spiral wound membrane (Koch Membrane Systems, Mass., U.S.A.) with a nominal separation cutoff of 10000 Daltons. After each production, the membrane was cleaned according to the same standard washing procedure as done before filtration. The retentate stream from the DF process was transferred to the spray-dryer as soon as the protein content reached the target value (total solids, $10 \pm 0.1 \%$, and protein content, $6.8 \pm 0.04 \%$ ). Protein was measured by a Rapid$\mathrm{N}$-Cube nitrogen/protein analyzer unit (Elementar, Germany). Concentrated whey protein was then spray dried (Niro Filterlab, Hudson, Wis., U.S.A.) with an inlet air temperature of $204{ }^{\circ} \mathrm{C}$ and an outlet air temperature of $88^{\circ} \mathrm{C}$ to obtain whey protein concentrate $65 \%$ protein (WPC65). The total filtration production time was approximately $2 \mathrm{~h}$ and spray-drying, approximately $45 \mathrm{~min}$. The manufactured WPC65 powder was packaged in Mylar bags (TF-4000 w/Zipper nr 41509, IMPAK Corp., Central City, S.Dak., U.S.A.) and shipped to North Carolina State Univ. by overnight carrier for sensory and instrumental analysis using previously described methods. Each WPC treatment and control was produced in duplicate in a completely randomized design on separate days.

Proximate analysis (fat, protein, moisture, and ash) was conducted in duplicate on each of the WPC using standard methods. Fat content was determined by the Mojonnier method (Mojonnier Bros. Co., Chicago, Ill., U.S.A.) (Atherton and Newlander 1977). Nitrogen content was determined by the Dumas method (Rapid-N-Cube nitrogen/protein analyzer unit) with a 6.38 protein factor (Kirsten and Hesselius 1983). Moisture and ash for WPC samples were analyzed by vacuum oven and ash oven, respectively, and quantified according to AOAC 
methods (AOAC 2007) (Isotemp Ash oven Model750, Fisher Scientific).

\section{Statistical analyses}

To determine if significant differences existed in sensory and volatile properties between liquid whey controls and treatments, analysis of variance (ANOVA, General Linear Model with repeated measures) was conducted for each whey type (Mozzarella, Cheddar) using XL-STAT (XL-STAT version 2009, Addinsoft, Paris, France). Both main effects (treatment, time) and interactions were investigated. Sensory and instrumental results from WPC were evaluated analogously. Principal component analysis was also applied to the correlation matrix of sensory and volatile component data to visualize how products were differentiated across sensory attributes or volatile components (XL-STAT).

\section{Results}

\section{Proximate analysis of liquid whey}

Liquid Cheddar and Mozzarella wheys were $6.50 \pm 0.10$ and $6.45 \pm 0.18$ percent solids and $1.40 \pm 0.20$ and $1.30 \pm 0.08$ percent protein, respectively. Percent fat content of Cheddar and Mozzarella whey prior to fat separation was $0.18 \pm 0.04$ and $0.21 \pm 0.05$, respectively, and after fat separation was $0.07 \pm 0.03$ for both whey types. The $\mathrm{pH}$ of both whey types was $6.38 \pm$ 0.05 and this value did not change with storage time $(P>0.05)$. Addition of ascorbic acid decreased $\mathrm{pH}(6.13 \pm 0.03)(P<0.05)$. These values were comparable to previous studies (CarunchiaWhetstine and others 2003; Gallardo-Escamilla and others 2005).

\section{Sensory analysis}

Liquid whey. Flavor terms documented in liquid wheys included aroma intensity, sweet aromatic, sour aromatic, cardboard, potato/brothy, cheesy/brothy, and cooked/milky (Table 1 and 2). Sour and sweet basic tastes, along with the feeling factor, astringency, were also documented. Previous research has identified these flavors in liquid whey (Carunchia-Whetstine and others 2003; Karagul-Yuceer and others 2003; Tomaino and others 2004; Gallardo-Escamilla and others 2005). Consistent with previous research (Tomaino and others 2004), the flavors of Cheddar and Mozzarella liquid whey changed with storage time $(P<$ $0.05)$. Flavor profiles were also distinct between the controls and treatments $(P<0.05)$. Fresh control wheys were characterized by cooked/milky and sweet aromatic flavors, fresh Mozzarella control whey were also characterized by sour aromatic flavor. Whey with ascorbic acid addition in either cheese type had higher intensities of sour taste, consistent with lower $\mathrm{pH}$ values. The WPH treated wheys were characterized by potato/brothy flavor and additionally in Cheddar whey, by cheesy/brothy flavor. These flavors have been previously associated with whey protein hydrolysates (Drake and others 2009).

Over storage time, control Cheddar wheys and Cheddar whey with ascorbic acid increased in cardboard flavor intensity with a simultaneous decrease in cooked/milky flavor. Cardboard flavor was highest in the unseparated fat control whey after $8 \mathrm{~d}$ storage. Similar changes were observed with Mozzarella whey (Table 2). As storage time increased, cardboard flavor intensity increased while cooked/milky flavor decreased in control and treated wheys (Table 2). Cooked/milky flavor was lower in WPH-treated whey compared to other wheys initially and this flavor decreased with storage time, similar to other wheys. After $8 \mathrm{~d}$ storage, Mozzarella
Table 1-Sensory flavor attributes of Mozzarella liquid whey over storage time.

\begin{tabular}{|c|c|c|c|c|c|}
\hline & \multicolumn{5}{|c|}{ Control 1} \\
\hline & $0 \mathrm{~d}$ & $2 \mathrm{~d}$ & $4 \mathrm{~d}$ & $6 \mathrm{~d}$ & $8 \mathrm{~d}$ \\
\hline Aroma intensity & 2.2 & 2.0 & 2.1 & 2.1 & 2.1 \\
\hline Sweet aromatic & 1.1 & 0.9 & 0.8 & 0.8 & 0.7 \\
\hline Sour aromatic & 1.1 & 0.8 & 0.5 & 0.6 & 0.7 \\
\hline Cardboard & ND & 0.8 & 1.1 & 1.4 & 1.6 \\
\hline Potato/brothy & ND & ND & ND & ND & ND \\
\hline Cooked/milky & 3.2 & 2.5 & 2.4 & 2.1 & 2.1 \\
\hline Sweet taste & 1.7 & 1.6 & 1.6 & 1.4 & 1.6 \\
\hline Sour taste & 1.0 & 0.8 & 0.8 & 1.0 & 0.8 \\
\hline \multirow[t]{3}{*}{ Astringent mouthfeel } & 1.2 & 1.3 & 1.3 & 1.4 & 1.3 \\
\hline & \multicolumn{5}{|c|}{ Control 2} \\
\hline & $0 \mathrm{~d}$ & $2 \mathrm{~d}$ & $4 \mathrm{~d}$ & $6 \mathrm{~d}$ & $8 \mathrm{~d}$ \\
\hline Aroma intensity & 1.9 & 1.5 & 1.7 & 1.9 & 2.0 \\
\hline Sweet aromatic & 1.1 & 0.9 & 0.7 & 0.6 & 0.6 \\
\hline Sour aromatic & 0.6 & 0.6 & 0.6 & 0.6 & 0.6 \\
\hline Cardboard & ND & ND & 0.9 & 1.1 & 1.6 \\
\hline Potato/brothy & ND & ND & ND & ND & ND \\
\hline Cooked/milky & 2.9 & 2.3 & 2.1 & 2.2 & 2.0 \\
\hline Sweet taste & 1.6 & 1.5 & 1.4 & 1.4 & 1.6 \\
\hline Sour taste & 1.0 & 0.7 & 0.8 & 0.8 & 0.9 \\
\hline \multirow[t]{3}{*}{ Astringent mouthfeel } & 1.2 & 1.3 & 1.2 & 1.4 & 1.3 \\
\hline & \multicolumn{5}{|c|}{ Ascorbic acid } \\
\hline & $0 \mathrm{~d}$ & $2 \mathrm{~d}$ & $4 \mathrm{~d}$ & $6 \mathrm{~d}$ & $8 \mathrm{~d}$ \\
\hline Aroma intensity & 1.8 & 1.7 & 1.8 & 1.9 & 1.7 \\
\hline Sweet aromatic & 0.7 & ND & 0.7 & 0.6 & ND \\
\hline Sour aromatic & 0.9 & 0.6 & 0.7 & 0.8 & 0.9 \\
\hline Cardboard & ND & ND & ND & ND & 0.8 \\
\hline Potato/brothy & ND & ND & ND & ND & ND \\
\hline Cooked/milky & 3.0 & 2.3 & 2.3 & 2.3 & 2.2 \\
\hline Sweet taste & 1.6 & 1.5 & 1.5 & 1.4 & 1.6 \\
\hline Sour taste & 1.5 & 1.2 & 1.2 & 1.1 & 1.1 \\
\hline \multirow[t]{3}{*}{ Astringent mouthfeel } & 1.2 & 1.3 & 1.3 & 1.4 & 1.3 \\
\hline & \multicolumn{5}{|c|}{ WPH } \\
\hline & $0 \mathrm{~d}$ & $2 d$ & $4 \mathrm{~d}$ & $6 \mathrm{~d}$ & $8 \mathrm{~d}$ \\
\hline Aroma intensity & 2.8 & 2.7 & 2.6 & 2.9 & 2.6 \\
\hline Sweet aromatic & ND & ND & ND & ND & ND \\
\hline Sour aromatic & ND & ND & ND & ND & ND \\
\hline Cardboard & ND & ND & ND & ND & ND \\
\hline Potato/brothy & 2.2 & 2.0 & 2.0 & 2.1 & 1.6 \\
\hline Cooked/milky & 2.1 & 1.7 & 1.5 & 1.5 & 1.7 \\
\hline Sweet taste & 1.7 & 1.4 & 1.5 & 1.4 & 1.4 \\
\hline Sour taste & 1.0 & 1.0 & 0.9 & 0.9 & 0.9 \\
\hline Astringent mouthfeel & 1.2 & 1.3 & 1.3 & 1.4 & 1.2 \\
\hline \multicolumn{6}{|c|}{ Interactions } \\
\hline & \multicolumn{2}{|c|}{ Trt } & Time & \multicolumn{2}{|r|}{ Trt $*$ Time } \\
\hline Aroma intensity & \multicolumn{2}{|c|}{$<0.0001$} & 0.005 & \multicolumn{2}{|r|}{ NS } \\
\hline Sweet aromatic & \multicolumn{2}{|c|}{$<0.0001$} & $<0.0001$ & \multicolumn{2}{|r|}{$<0.0001$} \\
\hline Sour aromatic & \multicolumn{2}{|c|}{$<0.0001$} & $<0.0001$ & \multicolumn{2}{|r|}{$<0.0001$} \\
\hline Cardboard & \multicolumn{2}{|c|}{$<0.0001$} & $<0.0001$ & \multicolumn{2}{|r|}{$<0.0001$} \\
\hline Potato/brothy & \multicolumn{2}{|c|}{$<0.0001$} & NS & & NS \\
\hline Cooked/milky & & & $<0.0001$ & & NS \\
\hline Sweet taste & & & 0.0002 & & NS \\
\hline Sour taste & & & $<0.0001$ & & NS \\
\hline Astringent mouthfeel & & & NS & & NS \\
\hline
\end{tabular}

$\mathrm{ND}=$ not detected. Interactions: Values $<0.05$ in $\operatorname{trt} *$ time indicate a significant interaction. NS $=$ not significant. Attributes were scored using a 0 to 15 -point universal Spectrum intensity scale where $0=$ absence of the attribute and $15=$ exversal spectro moval, Control 2-whey with fat removed, ascorbic acid - whey with fat removed and ascorbic acid addition, WPH-whey with fat removed and whey protein hydrolysate added. 
Table 2-Sensory flavor attributes of Cheddar liquid whey over storage time.

\begin{tabular}{|c|c|c|c|c|c|}
\hline & \multicolumn{5}{|c|}{ Control 1} \\
\hline & $0 \mathrm{~d}$ & $2 \mathrm{~d}$ & $4 \mathrm{~d}$ & $6 \mathrm{~d}$ & $8 \mathrm{~d}$ \\
\hline Aroma intensity & 2.4 & 2.1 & 2.1 & 2.3 & 2.0 \\
\hline Sweet aromatic & 2.0 & 1.5 & 0.8 & 1.1 & 0.5 \\
\hline Sour aromatic & ND & ND & ND & ND & ND \\
\hline Cardboard & ND & 1.0 & 1.8 & 1.9 & 2.5 \\
\hline Potato/brothy & ND & ND & ND & ND & ND \\
\hline Cheesy/brothy & ND & ND & ND & ND & ND \\
\hline Cooked/milky & 3.2 & 3.0 & 2.4 & 2.2 & 1.7 \\
\hline Sweet taste & 1.6 & 1.5 & 1.4 & 1.3 & 1.5 \\
\hline Sour taste & 0.5 & 0.5 & 0.5 & 0.5 & 0.5 \\
\hline \multirow[t]{3}{*}{ Astringent mouthfeel } & 1.5 & 1.5 & 1.5 & 1.5 & 1.5 \\
\hline & \multicolumn{5}{|c|}{ Control 2} \\
\hline & $0 \mathrm{~d}$ & $2 \mathrm{~d}$ & $4 \mathrm{~d}$ & $6 \mathrm{~d}$ & $8 \mathrm{~d}$ \\
\hline Aroma intensity & 2.4 & 2.0 & 2.1 & 2.0 & 2.0 \\
\hline Sweet aromatic & 2.0 & 1.3 & 0.8 & 1.0 & 0.5 \\
\hline Sour aromatic & ND & 0.1 & ND & ND & ND \\
\hline Cardboard & ND & 0.3 & 1.0 & 1.5 & 1.5 \\
\hline Potato/brothy & ND & ND & ND & ND & ND \\
\hline Cheesy/brothy & ND & ND & ND & ND & ND \\
\hline Cooked/milky & 3.2 & 3.0 & 2.6 & 2.4 & 2.0 \\
\hline Sweet taste & 1.6 & 1.5 & 1.4 & 1.5 & 1.6 \\
\hline Sour taste & 0.5 & 0.5 & 0.5 & 0.5 & 0.5 \\
\hline Astringent mouthfeel & 1.5 & 1.5 & 1.5 & 1.5 & 1.5 \\
\hline
\end{tabular}

\begin{tabular}{lccccc}
\hline & \multicolumn{5}{c}{ Ascorbic acid } \\
\cline { 2 - 6 } & $\mathbf{0 ~ d}$ & $\mathbf{2 ~ d}$ & $\mathbf{4 ~ d ~}$ & $\mathbf{6 ~ d}$ & $\mathbf{8 ~ d}$ \\
\hline Aroma intensity & 2.4 & 2.0 & 2.1 & 2.0 & 2.2 \\
Sweet aromatic & 1.7 & 1.1 & 1.0 & 1.3 & 1.0 \\
Sour aromatic & 0.8 & 0.6 & 0.6 & 0.8 & 1.0 \\
Cardboard & $\mathrm{ND}$ & $\mathrm{ND}$ & 0.6 & 0.9 & 0.8 \\
Potato/brothy & $\mathrm{ND}$ & $\mathrm{ND}$ & $\mathrm{ND}$ & $\mathrm{ND}$ & $\mathrm{ND}$ \\
Cheesy/brothy & $\mathrm{ND}$ & $\mathrm{ND}$ & $\mathrm{ND}$ & $\mathrm{ND}$ & $\mathrm{ND}$ \\
Cooked/milky & 3.0 & 3.1 & 2.6 & 2.5 & 2.3 \\
Sweet taste & 1.6 & 1.5 & 1.4 & 1.4 & 1.5 \\
Sour taste & 1.0 & 1.0 & 0.9 & 1.1 & 1.0 \\
Astringent mouthfeel & 1.5 & 1.5 & 1.5 & 1.5 & 1.5 \\
\hline & & & WPH & & \\
\cline { 2 - 6 } & $\mathbf{0 ~ d}$ & $\mathbf{2 ~ d}$ & $\mathbf{4 ~ d}$ & $\mathbf{6 ~ d}$ & $\mathbf{8} \mathbf{d}$ \\
\hline Aroma intensity & 2.9 & 2.0 & 3.0 & 3.0 & 2.8 \\
Sweet aromatic & 1.5 & 0.7 & $\mathrm{ND}$ & $\mathrm{ND}$ & $\mathrm{ND}$ \\
Sour aromatic & $\mathrm{ND}$ & $\mathrm{ND}$ & $\mathrm{ND}$ & $\mathrm{ND}$ & $\mathrm{ND}$ \\
Cardboard & $\mathrm{ND}$ & 0.3 & 0.8 & 0.8 & 0.5 \\
Potato/brothy & 2.7 & 1.8 & 2.3 & 2.5 & 1.9 \\
Cheesy/brothy & 1.3 & 2.0 & 1.5 & 1.6 & 1.3 \\
Cooked/milky & 2.9 & 2.7 & 1.8 & 1.9 & 1.8 \\
Sweet taste & 1.8 & 1.4 & 1.6 & 1.4 & 1.4 \\
Sour taste & 0.5 & 0.5 & 0.5 & 0.5 & 0.5 \\
Astringent mouthfeel & 1.5 & 1.5 & 1.5 & 1.5 & 1.5
\end{tabular}

\begin{tabular}{lccc}
\hline & \multicolumn{2}{c}{ Interactions } & \\
\hline & Trt & Time & Trt $*$ Time \\
\hline Aroma intensity & $<0.0001$ & 0.002 & $<0.0001$ \\
Sweet aromatic & $<0.0001$ & $<0.0001$ & 0.004 \\
Sour aromatic & $<0.0001$ & NS & NS \\
Cardboard & $<0.0001$ & $<0.0001$ & $<0.0001$ \\
Potato/brothy & $<0.0001$ & 0.0002 & $<0.0001$ \\
Cheesy/brothy & $<0.0001$ & NS & 0.025 \\
Cooked/milky & $<0.0001$ & $<0.0001$ & 0.017 \\
Sweet taste & NS & 0.0002 & NS \\
Sour taste & $<0.0001$ & 0.002 & NS \\
Astringent mouthfeel & NS & 0.002 & NS \\
\hline
\end{tabular}

$\mathrm{ND}=$ not detected. Interactions: Values $<0.05$ in trt $*$ time indicate a significant interaction. NS $=$ not significant. Attributes were scored using a 0 to 15 -point uniinteraction. $\mathrm{NS}=$ not significant. Attributes were scored using a to 15 -point uni-
versal Spectrum intensity scale where $0=$ absence of the attribute and $15=\mathrm{ex}-$ tremely high intensity of attribute. Most whey protein flavors fall between 0 and 4 (Drake and others 2003; Russell and others 2006). Control 1-whey with no fat removal, Control 2-whey with fat removed, ascorbic acid - whey with fat removed and ascorbic acid addition, WPH - whey with fat removed and whey protein hydrolysate added. whey controls with and without fat had similar cardboard flavor intensity.

Although flavor changes were similar over time, fresh and stored Mozzarella and Cheddar wheys had distinct flavor profiles $(P<$ 0.05) (results not shown). Mozzarella whey had lower intensities of sweet aromatic flavor than Cheddar whey while sour aromatic flavor was only documented in Mozzarella whey. This is in agreement with Gallardo-Escamilla and others (2005) who also reported that Mozzarella liquid whey had higher sour aromatic flavor intensity compared to Cheddar whey. Following storage, Cheddar whey had higher cardboard flavors compared to Mozzarella whey $(P<$ 0.05). Differences have also been documented between freshly manufactured Cheddar and Mozzarella WPC80, which also suggests that distinct flavors are present in the respective fresh fluid wheys (Drake and others 2009; Wright and others 2009). Different whey type flavors have been associated with the use of different starter cultures, milk source, and processing techniques to produce different types of cheese (Carunchia-Whetstine and others 2003; Gallardo-Escamilla and others 2005).

\section{Instrumental liquid whey results}

Volatiles identified in the liquid wheys included 2-methyl butanal, 3-methyl butanal, hexanal, heptanal, octanal, nonanal, decanal, 2-butanone, 3-hydroxy-2-butanone, 2-pentanone, 2heptanone, 2-nonanone, and 2,3-butanedione (Table 3 and 4). Previous research has identified most of these volatile compounds in liquid whey (Carunchia-Whetstine and others 2003; Karagul-Yuceer and others 2003; Tomaino and others 2004; Gallardo-Escamilla and others 2005). To our knowledge, decanal, 2-pentanone, and 3-hydroxy-2-butanone have not been documented in fresh liquid whey. Similar to sensory data, the volatile compound concentrations of Cheddar and Mozzarella whey samples changed over time in refrigerated storage. In general, fresh wheys had higher concentrations of 2,3-butanedione and 2-butanone and lower concentrations of all aldehydes compared to wheys stored $8 \mathrm{~d}$. Over storage, volatile lipid oxidation and lipid oxidation decomposition products such as aldehydes, hydrocarbons, alcohols, and olefins were documented.

Cheddar whey. Significant interactions between treatment and time occurred for 2-methyl butanal, 3-methyl butanal, hexanal, and heptanal concentrations in Cheddar whey (Table 3). As time progressed, concentrations of hexanal, heptanal, octanal, and nonanal increased in the control and treated wheys except for whey with WPH. Whey with WPH decreased in 2-methyl butanal, 3-methyl butanal, and hexanal concentration with a simultaneous increase in decanal concentration. The unseparated fat control (C1) at $8 \mathrm{~d}$ had the highest concentration of hexanal overall, while the whey with WPH had the highest concentration of decanal $(P<0.05)$.

The Cheddar liquid whey instrumental data were consistent with descriptive sensory results. Over time, control and treatments except whey with WPH, increased in cardboard flavor and also increased in hexanal, heptanal, octanal, and nonanal concentrations. Cardboard flavor intensities were highest in the unseparated and separated control wheys after $8 \mathrm{~d}$ storage and similarly, the control wheys had some of the highest concentrations of hexanal and heptanal. Whey with WPH was characterized by sensory analysis at all times by high intensities of cheesy/brothy and potato/brothy flavors, while instrumentally, this whey had high concentrations of 2-methyl butanal and 3-methyl butanal. These 2 aldehydes have been associated with malty and nutty flavors in cheese and milk (Avsar and others 2004). 
Mozzarella whey. Significant interactions in Mozzarella wheys occurred between treatment and time for 2-methyl butanal and 3-methyl butanal, octanal, heptanal, and hexanal, while nonanal concentrations changed only with time. Decanal was not detected in Mozzarella wheys (Table 4). Over $8 \mathrm{~d}$, the concentration of short chain aldehydes decreased $(P<0.05)$. Hexanal concentrations decreased in the separated fat control (Control 2) and all treatments. Hexanal concentration was highest after $2 \mathrm{~d}$ in Mozzarella control whey without fat removal and concentrations then decreased through $8 \mathrm{~d}$. Heptanal and octanal concentrations decreased or were not detected in wheys after $8 \mathrm{~d}$. Significant decreases in nonanal were documented in ascorbic acid and WPH

Table 3-Relative abundance of aldehydes (ppb) in Mozzarella liquid whey over storage time.

\begin{tabular}{|c|c|c|c|c|c|}
\hline & \multicolumn{5}{|c|}{ Control 1} \\
\hline & $0 \mathrm{~d}$ & $2 \mathrm{~d}$ & $4 d$ & $6 \mathrm{~d}$ & $8 \mathrm{~d}$ \\
\hline Nonanal & 0.0146 & 0.0162 & 0.0210 & 0.0149 & 0.00577 \\
\hline Octanal & 0.00111 & 0.000730 & 0.000786 & 0.000479 & ND \\
\hline Heptanal & 0.0167 & 0.0134 & 0.00507 & 0.00957 & 0.00394 \\
\hline Hexanal & 0.129 & 0.388 & 0.143 & 0.271 & 0.150 \\
\hline 2-Methyl Butanal & ND & ND & ND & ND & ND \\
\hline \multirow[t]{3}{*}{ 3-Methyl Butanal } & ND & ND & ND & ND & ND \\
\hline & \multicolumn{5}{|c|}{ Control 2} \\
\hline & $0 \mathrm{~d}$ & $2 \mathrm{~d}$ & $4 d$ & $6 \mathrm{~d}$ & $8 \mathrm{~d}$ \\
\hline Nonanal & 0.0232 & 0.0128 & 0.0218 & 0.0429 & 0.0421 \\
\hline Octanal & 0.00198 & 0.000463 & 0.00141 & 0.00164 & ND \\
\hline Heptanal & 0.0108 & 0.00827 & 0.00558 & 0.00590 & 0.000754 \\
\hline Hexanal & 0.0654 & 0.152 & 0.211 & 0.204 & 0.0667 \\
\hline 2-Methyl Butanal & ND & ND & ND & ND & ND \\
\hline \multirow[t]{3}{*}{ 3-Methyl Butanal } & ND & ND & ND & ND & ND \\
\hline & \multicolumn{5}{|c|}{ Ascorbic acid } \\
\hline & $0 \mathrm{~d}$ & $2 \mathrm{~d}$ & $4 d$ & $6 \mathrm{~d}$ & $8 \mathrm{~d}$ \\
\hline Nonanal & 0.0371 & 0.0399 & 0.0532 & 0.0441 & 0.00936 \\
\hline Octanal & 0.00552 & 0.00850 & 0.00986 & 0.00506 & 0.00160 \\
\hline Heptanal & 0.0112 & 0.0174 & 0.0188 & 0.00623 & 0.00112 \\
\hline Hexanal & 0.0656 & 0.1025 & 0.0991 & 0.0378 & 0.00443 \\
\hline 2-Methyl Butanal & ND & ND & ND & ND & ND \\
\hline \multirow[t]{3}{*}{ 3-Methyl Butanal } & ND & ND & ND & ND & ND \\
\hline & \multicolumn{5}{|c|}{ WPH } \\
\hline & $0 \mathrm{~d}$ & $2 \mathrm{~d}$ & $4 d$ & $6 \mathrm{~d}$ & $8 \mathrm{~d}$ \\
\hline Nonanal & 0.0371 & 0.0363 & 0.0308 & 0.0429 & 0.0081 \\
\hline Octanal & 0.00493 & 0.00732 & 0.00784 & 0.00609 & ND \\
\hline Heptanal & 0.0298 & 0.0323 & 0.0205 & 0.0181 & ND \\
\hline Hexanal & 0.1817 & 0.2228 & 0.1206 & 0.0988 & 0.00329 \\
\hline 2-Methyl Butanal & 0.206 & 0.428 & 0.387 & 0.262 & 0.0408 \\
\hline 3-Methyl Butanal & 0.499 & 0.598 & 0.327 & 0.204 & 0.0441 \\
\hline \multicolumn{6}{|c|}{ Interactions } \\
\hline & \multicolumn{2}{|c|}{ Trt } & \multicolumn{2}{|l|}{ Time } & Trt $*$ Time \\
\hline Nonanal & \multicolumn{2}{|c|}{ NS } & \multicolumn{2}{|l|}{0.0008} & NS \\
\hline Octanal & \multicolumn{2}{|c|}{$<0.0001$} & \multicolumn{2}{|l|}{$<0.0001$} & NS \\
\hline Heptanal & \multicolumn{2}{|c|}{$<0.0001$} & \multicolumn{2}{|l|}{$<0.0001$} & NS \\
\hline Hexanal & \multicolumn{2}{|c|}{0.0002} & \multicolumn{2}{|l|}{0.0002} & NS \\
\hline 2-Methyl Butanal & \multirow{2}{*}{\multicolumn{2}{|c|}{$\begin{array}{l}<0.0008 \\
<00001\end{array}$}} & \multicolumn{2}{|l|}{$<0.0001$} & $<0.0001$ \\
\hline 3-Methyl Butanal & & & \multicolumn{2}{|l|}{$<0.0001$} & $<0.0001$ \\
\hline
\end{tabular}

$\mathrm{ND}=$ not detected. Interactions: Values $<0.05$ in $\operatorname{trt} *$ time indicate a significant in teraction. Attributes where interactions are not significant may be significant within treatment or time if $<0.05$. NS $=$ not significant. Control 1 -whey with no fat removal, Control 2-whey with fat removed, ascorbic acid - whey with fat removed and ascorbic acid addition, WPH-whey with fat removed and whey protein hydrolysate added. RI values for volatile compounds on a ZB-5 column are listed in Table 7. treatments. Mozzarella liquid whey controls initially had similar aldehyde concentrations. After storage, whey with fat separation had a higher concentration of nonanal and a lower amount of heptanal compared to the control whey without fat removal. Similar decreases in relative abundance of aldehydes over storage have been documented with WPC and WPI studies (Javidipour and Qian 2008; Wright and others 2009). For Mozzarella whey, total aldehyde concentration increased up to $4 \mathrm{~d}$ and then decreased until $8 \mathrm{~d}$.

Table 4-Relative abundance of aldehydes (ppb) in Cheddar liquid whey over storage time.

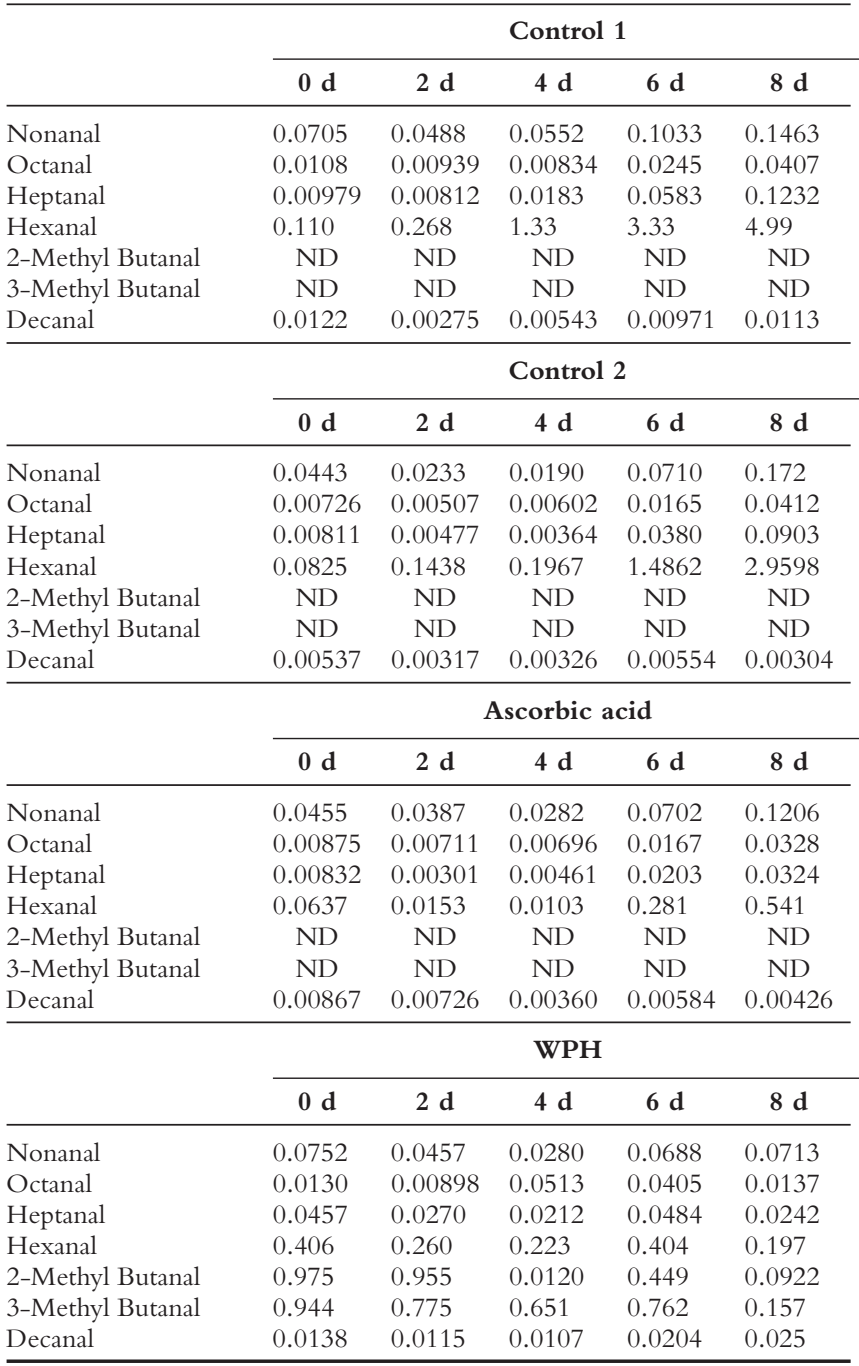

Interactions

\begin{tabular}{lccc}
\hline & Trt & Time & Trt $*$ Time \\
\hline Nonanal & NS & $<0.0001$ & NS \\
Octanal & NS & 0.0176 & NS \\
Heptanal & 0.0102 & $<0.0001$ & $<0.0001$ \\
Hexanal & $<0.0001$ & $<0.0001$ & $<0.0001$ \\
2-Methyl Butanal & $<0.0001$ & $<0.0001$ & $<0.0001$ \\
3-Methyl Butanal & $<0.0001$ & $<0.0001$ & $<0.0001$ \\
Decanal & $<0.0001$ & 0.027 & NS
\end{tabular}

$\mathrm{ND}=$ not detected. Interactions: Values $<0.05$ in trt $*$ time indicate a significant interaction. Attributes where interactions are not significant may be significant within treatment or time if $<0.05$. NS $=$ not significant. Control 1 -whey with no fat removal, Control 2-whey with fat removed, ascorbic acid-whey with fat removed and ascorbic acid addition, WPH-whey with fat removed and whey protein hy drolysate added. RI values for volatile compounds on a ZB-5 column are listed in Table 7. 
Mozzarella liquid whey instrumental results were consistent with descriptive sensory data in that the volatile composition of Mozzarella liquid whey was very different from Cheddar liquid whey as were the sensory profiles of these 2 whey types. However, unlike Cheddar whey, increases in cardboard flavor over time for Mozzarella liquid wheys were not concurrent with increased aldehyde concentrations after $8 \mathrm{~d}$. Instead of an increase in short chain aldehyde concentration over $8 \mathrm{~d}$, there was an increase up to 4 to $6 \mathrm{~d}$, followed by a decrease in concentration at $8 \mathrm{~d}$. This may be due to the further degradation of the aldehydes into other compounds or reaction with sulfur compounds. For example, hexanal can degrade into hexanoic acid (Schieberle and Grosch 1981) and both saturated and unsaturated aldehydes can react with hydrogen sulfide and thiol compounds (Boelens and others 1974). Alternatively, aldehydes may bind to proteins and thus appear to decrease in concentration. However, given that the protein concentration of Cheddar and Mozzarella wheys are similar, if protein binding occurred, we would have expected to observe similar changes with Cheddar whey. As observed in Tables 3 and 4, aldehyde concentrations were not always lower in Mozzarella liquid whey compared to Cheddar liquid whey. Mozzarella control whey and treatments actually had higher concentrations of specific aldehydes, most commonly heptanal, up until $4 \mathrm{~d}$. After $4 \mathrm{~d}$, Cheddar liquid wheys increased in aldehyde concentration while Mozzarella samples decreased. Little research has been conducted on Mozzarella liquid whey. Gallardo-Escamilla and others (2005) compared liquid wheys of various cheese types and similar to our results, concluded that Mozzarella fluid whey was different in flavor and volatile profile from Cheddar liquid whey.

\section{Whey protein concentrate}

Cheddar whey was selected for WPC manufacture. Results from liquid whey trials indicated that Mozzarella liquid whey did not change as drastically as Cheddar liquid whey over time by sensory or instrumental analysis. Previous studies have also documented that Mozzarella WPC80 has a distinct and mild flavor and generally lower concentrations of all volatile compounds over storage time than Cheddar WPC (Wright and others 2009), suggesting that further antioxidant research would be more beneficial for Cheddar whey than Mozzarella whey. The separated fat control and the treatments ascorbic acid and WPH were selected for WPC production.

Analysis of whey protein concentrate. Gross composition of Cheddar WPC are listed in Table 5. Flavors documented in the WPC samples included attributes previously noted in liquid whey with the addition of cereal, malty, and serum/oxidized flavors (Table 6). Previous research has documented these flavors in WPC (Carunchia-Whetstine and others 2005; Russell and others 2006; Evans and others 2009; Wright and others 2009). Similar to liquid

Table 5- Gross composition of WPC (mean \pm standard deviation).

\begin{tabular}{llcc}
\hline & \multicolumn{3}{c}{ Composition } \\
\cline { 2 - 4 } WPC sample & Moisture, \% & Fat, \% & Protein, \% \\
\hline Control & $6.02 \pm 0.50 \mathrm{a}$ & $20.5 \pm 1.52 \mathrm{a}$ & $64.0 \pm 0.67 \mathrm{a}$ \\
Ascorbic acid & $4.55 \pm 0.73 \mathrm{ab}$ & $22.2 \pm 3.15 \mathrm{a}$ & $66.6 \pm 1.31 \mathrm{a}$ \\
WPH & $3.10 \pm 0.33 \mathrm{~b}$ & $24.9 \pm 2.97 \mathrm{a}$ & $65.0 \pm 1.06 \mathrm{a}$ \\
\hline
\end{tabular}

Means are from duplicate analyses from 2 experimental replications. Means in a column followed by different letters are different $(P<0.05)$. Control—no treatment, ascorbic acid—added ascorbic acid, WPH—added whey protein hydrolysate. whey, potato/brothy and malty flavors were only detected in the WPH treatment. Only the control WPC was characterized by a serumy/oxidized flavor and the WPC control had the highest intensities of cardboard flavor and aroma intensity $(P<0.05$, Table 5).

Volatiles identified in Cheddar WPC included 2-methyl butanal, 3-methyl butanal, pentanal, hexanal, heptanal, octanal, nonanal, dimethyl disulfide (DMDS), 2-heptanone, 1-pentanol, 2,5-octanedione, 2-pentyl furan, butanoic acid, and hexanoic acid (Table 7 and Figure 1). Previous research has documented these volatile compounds in Cheddar WPC (Stevenson and Chen 1996; Mills and Broome 1997; Quach and others 1999; Mahajan and others 2004; Carunchia-Whetstine and others 2005; Wright and others 2009). As with fluid whey, the compounds 2-methyl butanal and 3-methyl butanal were only detected in WPC with added WPH.

The control WPC had significantly higher amounts of pentanal, (E,Z)-2,6-nonadienal, 2-heptanone, butanoic acid, and hexanoic acid than the 2 treated WPC. WPC with ascorbic acid had

Table 6-Sensory flavor attributes of Cheddar WPC.

\begin{tabular}{lcccc}
\hline & \multicolumn{4}{c}{ Mean scores } \\
\cline { 2 - 5 } & $\begin{array}{c}\text { WPC } \\
\text { control }\end{array}$ & $\begin{array}{c}\text { WPC with } \\
\text { ascorbic acid }\end{array}$ & $\begin{array}{c}\text { WPC with } \\
\text { WPH }\end{array}$ & LSD \\
\hline Aroma intensity & $2.5 \mathrm{a}$ & $2.1 \mathrm{~b}$ & $1.5 \mathrm{c}$ & 0.28 \\
Sweet aromatic & $1.1 \mathrm{a}$ & $1.1 \mathrm{a}$ & $\mathrm{ND}$ & 0.10 \\
Cardboard & $2.0 \mathrm{a}$ & $1.5 \mathrm{~b}$ & $1.1 \mathrm{~b}$ & 0.41 \\
Potato/brothy & $\mathrm{ND}$ & $\mathrm{ND}$ & $0.90 \mathrm{a}$ & 0.23 \\
Cereal & $1.8 \mathrm{a}$ & $1.5 \mathrm{a}$ & $1.3 \mathrm{a}$ & 0.63 \\
Malty & $\mathrm{ND}$ & $\mathrm{ND}$ & $1.1 \mathrm{a}$ & 0.13 \\
Serum/oxidized & $1.1 \mathrm{a}$ & $\mathrm{ND}$ & $\mathrm{ND}$ & 0.09 \\
Cooked/milky & $1.1 \mathrm{~b}$ & $1.5 \mathrm{a}$ & $\mathrm{ND}$ & 0.34 \\
Astringent & $1.6 \mathrm{a}$ & $1.6 \mathrm{a}$ & $1.8 \mathrm{a}$ & 0.42 \\
Sweet & $1.3 \mathrm{a}$ & $1.3 \mathrm{a}$ & $1.4 \mathrm{a}$ & 0.18 \\
\hline
\end{tabular}

Means followed by different lowercase letters within a treatment for an attribute signify a difference $(P<0.05)$. Attributes were scored using a 0 to 15 -point universal Spectrum intensity scale where $0=$ absence of the attribute and $15=$ extremely high intensity of attribute. Most whey protein flavors fall between 0 and 4 (Drake and others 2003; Russell attribute. Most whey protein flavors fall between 0 and
and others 2006). LSD = least significant difference.

Table 7- Relative abundance of volatile compounds (ppb) in Cheddar WPC.

\begin{tabular}{|c|c|c|c|c|c|}
\hline Compounds & $\begin{array}{c}\text { RI } \\
\text { (ZB5) }\end{array}$ & $\begin{array}{c}\text { WPC } \\
\text { Control }\end{array}$ & $\begin{array}{l}\text { WPC } \\
\text { with } \\
\text { ascorbic } \\
\text { acid }\end{array}$ & $\begin{array}{c}\text { WPC } \\
\text { with } \\
\text { WPH }\end{array}$ & LSD \\
\hline Methional & 925 & $0.155 b$ & $0.155 b$ & $0.403 \mathrm{a}$ & 0.125 \\
\hline 2-Methyl Butanal & 647 & ND & ND & $3.28 \mathrm{a}$ & 0.784 \\
\hline 3-Methyl Butanal & 637 & ND & ND & $5.00 \mathrm{a}$ & 0.622 \\
\hline Pentanal & 695 & $3.22 \mathrm{a}$ & $1.69 \mathrm{~b}$ & $1.06 \mathrm{~b}$ & 1.20 \\
\hline Hexanal & 801 & $104 \mathrm{a}$ & $90.2 \mathrm{a}$ & $43.8 b$ & 37.6 \\
\hline Heptanal & 882 & $8.20 \mathrm{a}$ & $6.29 a$ & $1.74 b$ & 2.27 \\
\hline Octanal & 995 & $0.795 b$ & $1.14 \mathrm{a}$ & ND & 0.154 \\
\hline Nonanal & 1096 & $1.33 \mathrm{ab}$ & $3.69 \mathrm{a}$ & ND & 2.80 \\
\hline$(\mathrm{E}, \mathrm{Z})-2,6-$ Nonadienal & 1149 & $1.56 \mathrm{a}$ & $0.443 b$ & $0.295 b$ & 0.217 \\
\hline Dimethyl Disulfide & 744 & $0.0772 \mathrm{a}$ & $0.0535 \mathrm{a}$ & ND & 0.0901 \\
\hline Dimethyl Trisulfide & 960 & $0.656 \mathrm{a}$ & $0.829 \mathrm{a}$ & $0.449 b$ & 0.196 \\
\hline 1-Pentanol & 773 & $0.747 \mathrm{a}$ & $0.324 \mathrm{a}$ & $0.708 \mathrm{a}$ & 0.544 \\
\hline 2,3-Butanedione & $<600$ & $3.62 b$ & $8.10 \mathrm{a}$ & $3.49 b$ & 3.23 \\
\hline 2-Heptanone & 894 & $2.07 \mathrm{a}$ & $1.05 b$ & $0.288 \mathrm{c}$ & 0.533 \\
\hline 1-Octen-3-one & 973 & $1.37 \mathrm{a}$ & $1.02 \mathrm{a}$ & $1.46 \mathrm{a}$ & 0.512 \\
\hline 2,5-Octanedione & 985 & $1.57 \mathrm{a}$ & $1.79 \mathrm{a}$ & $0.453 b$ & 0.779 \\
\hline 2-Pentyl Furan & 988 & $3.00 \mathrm{a}$ & $2.50 \mathrm{a}$ & $0.474 b$ & 1.23 \\
\hline Butanoic acid & 835 & $1.58 \mathrm{a}$ & $0.00880 \mathrm{~b}$ & ND & 0.957 \\
\hline Hexanoic acid & 1024 & $1.68 \mathrm{a}$ & $0.103 \mathrm{~b}$ & $0.00743 b$ & 0.876 \\
\hline
\end{tabular}

Means followed by different lowercase letters within a treatment for a compound signify a difference $(P<0.05)$. ND $=$ not detected. $\mathrm{LSD}=$ least significant difference. RI-retention indices of the volatile compound on the ZB-5 column. 
higher concentrations of octanal than the WPC control and higher concentrations of hexanal, heptanal, DMTS, 2,3-butanedione, 2heptanone, 2-pentyl furan, and 2,5-octanedione than WPC with WPH. Octanal, nonanal, butanoic acid, and DMDS were not detected in WPC with WPH while 2-methyl butanal and 3-methyl butanal were only detected in WPC with WPH. Methional concentration was significantly higher in WPC with WPH compared to control and ascorbic acid treated WPC. The volatile compounds detected represent a range of Maillard browning, lipid oxidation, or fermentation compounds. Many of the compounds found in WPC, especially the aldehydes and ketones, confirm the evolution of lipid oxidation during storage and were further confirmed with sensory results (Carunchia-Whetstine and others 2005; Wright and others 2009).

Propanal, pentanal, hexanal, heptanal, octanal, nonanal, decanal, nonadienals, 1-pentanol, 2-pentyl furan, and 2-heptanone are products of free fatty acid decomposition (Frankel 1998). Pentanal (Carunchia-Whetstine and others 2003; Tomaino and others 2004), hexanal (Quach and others 1999; Wright and others 2009), nonanal (Tomaino and others 2004), (E,Z)-2,6-nonadienal (Karagul-Yuceer and others 2003), 1-octen-3-one (CarunchiaWhetstine and others 2005), and 2-heptanone (Quach and others
1999) have been associated with stale, cardboard flavors in whey and dairy powders. In agreement with previous studies, hexanal was the most abundant compound quantified in WPC (Quach and others 1999; Wright and others 2009). Methional, DMDS, and DMTS have also been documented in commercial WPC and WPI (Mahajan and others 2004; Wright and others 2009). Methional is a Strecker degradation product formed from the degradation of methionine. From methionine, DMDS and DMTS are further degradation products from intermediate products methanethiol and dimethyl sulfide (Wright and others 2006). Butanoic and hexanoic acid concentrations in the control WPC were similar to those previously reported in WPC (CarunchiaWhetstine and others 2005).

\section{Discussion}

\section{Lipid autoxidation in fluid whey and WPC}

Autoxidation of unsaturated fatty acids gives rise to unstable hydroperoxides, which decompose to a wide range of carbonyl products, many of which can contribute to off-flavors in dairy products (Lee and Morr 1994; O'Connor and O'Brien 2006; Drake and others 2009; Wright and others 2009). Short chain

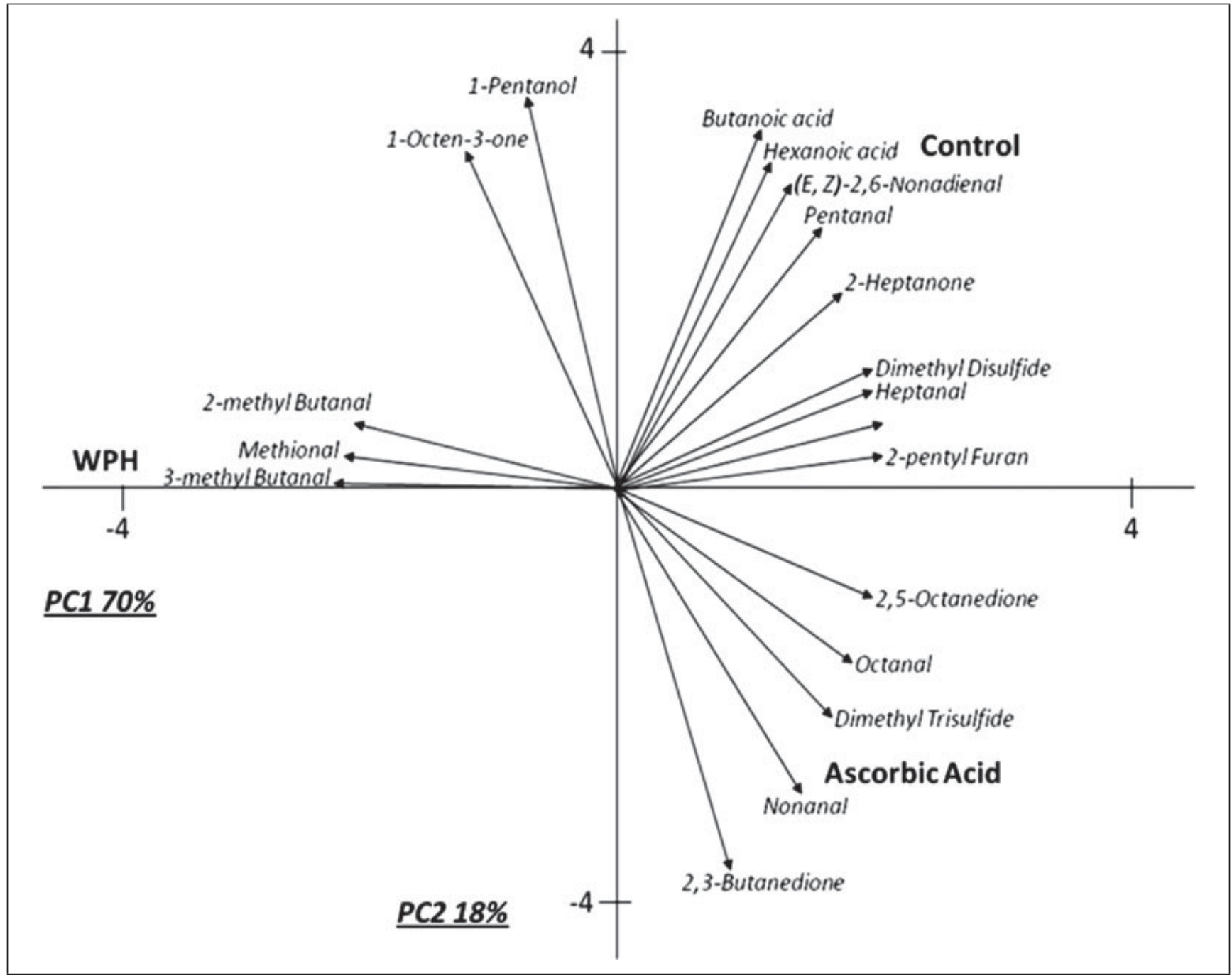

Figure 1-Principal component biplot of Cheddar WPC volatile compounds and WPC treatments. Control: Control with fat separation; ascorbic acid: whey with ascorbic acid addition; WPH treatment: whey with WPH addition. 
aldehyde detection and increases with storage have been previously documented in Cheddar liquid whey (Carunchia-Whetstine and others 2003; Tomaino and others 2004; Gallardo-Escamilla and others 2005). Tomaino and others (2004) suggested that the actual cheese making process initiated the production of these compounds, which then increased in concentration over storage time and/or processing, an observation confirmed in the current study with Cheddar and Mozzarella wheys.

Previous studies have quantified the amounts of free fatty acids in Cheddar liquid whey (Tomaino and others 2001, 2004; Carunchia-Whetstine and others 2003). Over $14 \mathrm{~d}$ of liquid whey storage, significant decreases in palmitic (C: 16), oleic (C18:1 $1 \omega 9)$, and linoleic $(\mathrm{C} 18: 2 \omega 6)$ free fatty acids with subsequent increases in lipid oxidation products were documented (Tomaino and others 2004). Further, significant correlations were documented between the decrease in linoleic acid concentration and increases in cardboard flavor over storage (Tomaino and others 2004). Hexanal was the predominant aldehyde detected in this and other storage studies with Cheddar liquid whey and whey products (Quach and others 1999; Tomaino and others 2004; Carunchia-Whetstine and others 2005).

Starter cultures may also form lipid oxidation products during fermentation. Lactic acid bacteria, Lactococcus cremoris, Lactococcus lactis, Streptococcus thermophilus, Lactobacillus helveticus, and Lactobacillus bulgaricus, produced 2,4-decadienal and 2,4-nonadienal in milk (Suriyaphan and others 2001). Degradation of 2,4-decadienal serves as yet another pathway for hexanal production (Schieberle and Grosch 1981). In the current study, volatile acetic, butanoic, and hexanoic acids were significantly higher in Cheddar whey over $8 \mathrm{~d}$ storage compared to Mozzarella whey. Of these 3 acids, only acetic acid was detected in Mozzarella whey with fat. In the current study, Cheddar liquid whey had more lipid oxidation than Mozzarella liquid whey based on the total aldehyde concentrations identified in the whey samples.

For Cheddar and Mozzarella whey, fat separation decreased aldehyde production and lipid oxidation products (Table 3 and 4), confirming that efficient fat separation is a critical parameter in industrial whey processing. Few sensory differences were documented between the 2 Mozzarella control wheys. However, control Mozzarella wheys had similar aldehyde concentrations initially, but over time, the fat separated control had a lower concentration of total aldehydes than the control whey without fat separation (Table 2 and 4). In Cheddar wheys, controls had a similar sensory and volatile profiles initially, and over time, whey without fat removal had significantly higher cardboard flavor and higher concentrations of hexanal and total aldehydes than whey with fat removed (Table 3).

The increase and subsequent decrease of aldehyde concentrations in Mozzarella liquid whey over $8 \mathrm{~d}$ may be explained by the autoxidation of saturated aldehydes (Table 4). For example, hexanal and octanal produce hexanoic and octanoic acids, respectively, by autoxidation (Schieberle and Grosch 1981) and nonanal produces octanal, octanol, hexanal, heptanal (Forney 1974), and nonanoic acid (Lillard and Day 1964). Saturated aldehydes degrade significantly slower than unsaturated aldehydes and in the presence of unsaturated aldehydes, oxidation of saturated aldehydes is decreased (Schieberle and Grosch 1981). Thus, the initial concentration of free fatty acids in whey may first determine the concentration of aldehydes, that is, lipid oxidation products, followed by the degradation of unsaturated aldehydes and then finally degradation of the saturated aldehydes into carboxylic acids. In relation to the current study, liquid wheys without fat removal, es- pecially Cheddar whey, had the highest cardboard flavor intensities and aldehyde concentrations. This is most likely due to an initial higher concentration of fat and free fatty acids than wheys with fat removal. Whey without fat removal, especially Cheddar whey, may have higher lipid oxidation products than Mozzarella whey due to its higher initial free fatty acid and unsaturated aldehyde concentration.

Approximately $0.2 \%$ residual lipids are left in liquid whey, which amount to $5 \%$ to $7 \%$ fat when the whey is concentrated into WPC (Morr and Ha 1993). These lipids that remain in the whey even after fat separation are believed to be released from the milkfat globule membrane into the whey during cheesemaking (Morr and Ha 1991). Phospholipids have also been considered as a possible source of off-flavors in whey products (Morr and Ha 1993). Phospholipids of milk and dairy products are concentrated in either the milk fat globule membrane (MFGM) or in other membraneaceous material that are probably derived from the MFGM (Christie and others 1987). The MFGM consists mainly of triacylglycerides, cholesterol, phospholipids, and sphingolipids in varying proportions (Fox and McSweeney 1998). During processing, the MFGM may be disrupted, releasing MFGM and its contents into the skim milk phase and enriching the aqueous phase (Christie and others 1987; Rombaut and Dewettinck 2006). Before processing, fat rich products are high in polar lipids as they are situated on the MFGM, but after processing and subsequent MFGM rupturing, low fat products such as skim milk, buttermilk, butterserum (aqueous phase of butter), and whey also become enriched in polar lipids (Christie and others 1987; Rombaut and Dewettinck 2006). In cream, butter and cheese, polar lipids are less than $1 \%(\mathrm{w} / \mathrm{w})$ of total lipids, but the concentration is much higher in skimmed products like whey (Rombaut and Dewettinck 2006). Phospholipids are more unsaturated than the triglyceride fraction of milk (Rombaut and Dewettinck 2006). Cheddar and Mozzarella liquid whey, when manufactured from whole milk as was the case in the current study, have very similar concentrations of phospholipid polar species (Rombaut and others 2007).

Overall, lipid oxidation in whey products consists of a variety of pathways to produce off-flavors and oxidative products. It seems likely that phospholipids play a role in the oxidative products in Cheddar and Mozzarella whey. However, different amounts of lipid oxidation products were documented between the 2 types of whey, despite similar total lipid concentrations in the wheys and in the initial cheesemilks, suggesting the role of other influencing factors such as the type of starter culture.

Whey made from different types of cheese have different flavor profiles (Carunchia-Whetstine and others 2003; GallardoEscamilla and others 2005), and studies with fermented milks have confirmed a wide variety in type and amount of volatile compound production from Lactobacillus strains and Lactococcus species (Boumerbassi and others 1995). Strain differences in Cheddar starter cultures can also influence the flavor and oxidative stability of liquid Cheddar whey (Carunchia-Whetstine and others 2003; Tomaino and others 2004). Thus, it should be no surprise to find vast differences between Cheddar and Mozzarella liquid whey and oxidative stability of these products. Lipid oxidation products, prevalent in liquid whey, were also observed in WPC. Lipid oxidation products are primary contributors to the flavor of WPC34, WPC80, and WPI (Carunchia Whetstine and others 2005; Evans and others 2009). Previous studies have similarly demonstrated that flavors and flavor compounds documented in fluid whey are indicative of flavors in spray-dried WPC (Croissant and others 2009). 
Ascorbic acid. Lipid oxidation may be inhibited with the addition of antioxidants. Ascorbic acid is a natural and promising antioxidant for food systems. Ascorbic acid can be described as an antioxidant, prooxidant, metal chelator, reducing agent, and oxygen scavenger (Frankel 1998). As an antioxidant, ascorbic acid acts as a radical scavenger by reacting with radicals to form less reactive radicals. Ascorbic acid can inhibit or retard hydroperoxide decomposition and ultimately aldehyde formation by interfering with propagation or initiation by hydrogen donation to the radicals (Niki and others 1984; Frankel 1998). The addition of ascorbic acid in this study produced an antioxidant effect in liquid whey and Cheddar WPC. Cardboard flavor in liquid and WPC were significantly lower in whey with ascorbic acid addition compared to control whey. Ascorbic acid addition also resulted in lower total aldehyde concentration in liquid whey and WPC compared to control whey and WPC. However, addition of ascorbic acid to liquid whey seemed to exhibit a greater antioxidant effect compared to its effect in the finished dried product WPC. In liquid whey, both treatments had similar reduced concentrations of aldehydes over storage time. Conversely, in WPC, ascorbic acid did not maintain the same aldehyde inhibiting effects as WPC with WPH (Table 3 and 4). This initial ascorbic acid antioxidant activity with subsequent decrease in activity has been observed in previous research with other foods (Villota and Karel 1980; Robertson and Samaniego 1986; Dave and Shah 1997). As ascorbic acid is consumed as an antioxidant, the concentration of ascorbic acid will eventually fall in the prooxidant range and begin to produce more radicals than it is able to scavenge (Mahoney and Graf 1986). Over storage time, ascorbic acid will degrade and antioxidant activity is no longer exhibited (Saguy and others 1978; Robertson and Samaniego 1986).

Whey protein hydroylsate. Previous studies have demonstrated that food proteins and their hydrolysates have antioxidant activity including milk proteins, casein (Cervato and others 1999; Wong and Kitts 2003), casein hydrolysates and low molecular weight casein hydrolysates (Diaz and Decker 2004), whey protein hydrolysates (Peña-Ramos and Xiong 2003), egg yolk (Park and others 2001), and soybean protein hydrolysate (Chen and others 1996; Peña-Ramos and Xiong 2003). Model systems have demonstrated that the antioxidative properties of whey proteins can be increased by fractionation or hydrolysis with certain enzymes, as some peptides and fractions possess stronger antioxidative effects than others (Peña-Ramos and Xiong 2001; Hernandez-Ledesma and others 2005; Pihlanto 2006). In this study, WPH addition to liquid whey and further production to spray-dried WPC successfully led to a decrease in cardboard flavor and short chain aldehyde concentration compared to the control liquid whey and WPC.

Previous research has attributed lipid oxidation inhibition by enzymatic hydrolysis of proteins to metal chelation and termination of radicals due to specific amino acid residue side chains or through the specific peptide structure (Yamashoji and Kajimoto 1980; Peña-Ramos and Xiong 2001). The accessibility to the peptides may also alter the antioxidant effect. Smaller peptides and amino acids have greater accessibility compared to larger peptides and proteins (Moosman and Behl 2002). Previous research with soy protein (Chen and others 1995) and casein (Suetsana and others 2000) attributed the antioxidant success of shorter peptides to specific amino acids. In whey, Peña-Ramos and Xiong (2001) suggested peptides with low molecular weights, $<10 \mathrm{kDa}$, contributed to the antioxidant activity of WPH.

Although whey with WPH had lower cardboard flavor in liquid whey and WPC products, WPH has its own distinct flavor and aroma as well (Drake and others 2009). Whey with WPH had potato/brothy, cheesy/brothy, and malty flavors that were not detected in the control samples. WPC, after further processing, had lower intensities of these flavors than the liquid whey with the same added WPH concentration, but WPH-specific flavors were still evident. Further research should be conducted to determine if lower concentrations of WPH or different types of WPH will minimize WPH-flavor in WPC while maintaining or enhancing antioxidant effects.

\section{Conclusions}

Mozzarella and Cheddar liquid whey had distinct flavor profiles, volatile compound concentrations, and oxidative stability. Lipid oxidation occurred in Mozzarella and Cheddar liquid whey over storage time. However, lipid oxidation products were more prevalent in Cheddar whey than Mozzarella whey, which may contribute to flavor differences in dried whey proteins. Fat removal from liquid whey decreased but did not eliminate lipid oxidation. The addition of ascorbic acid or WPH to either liquid whey type decreased cardboard off-flavor and aldehyde concentration over time, and WPH was most effective as an antioxidant in finished Cheddar WPC. Ascorbic acid antioxidant activity may become exhausted through the production of the dried whey product, thus exhibiting less antioxidant properties than WPH. Hexanal was the most abundant volatile compound found in liquid whey and WPC. These results suggest that lipid oxidation is evident in fresh liquid whey and steps should be taken to further minimize lipid oxidation during whey processing. The addition of antioxidants may enhance quality of WPC.

\section{Acknowledgments}

Funding was provided in part by Dairy Management, Inc. (Rosemont, Ill., U.S.A.). This study is paper FSR 10-15 of the Dept. of Food, Bioprocessing and Nutritional Sciences, North Carolina State Univ. Mention of trade names does not imply endorsement or lack of endorsement by those not mentioned. The assistance of R. Evan Miracle with the instrumental analysis is gratefully acknowledged.

\section{References}

Assn. of Official Analytical Chemists [AOAC]. 2007. Association of official analytical chemists. 18 th ed. Official methods of analysis (Nr 927.05; 930.30; 974.09; 930.29). Washington, D.C.: AOAC.

Atherton HV, Newlander JA. 1977. The chemistry and testing of milk and dairy products. 4th ed. Westport, Conn.: AVI Publ. Co., Inc.

Avsar YK, Karagul-Yuceer Y, Drake MA, Singh TK, Yoon Y, Cadwaller KR. 2004. Characterization of nutty flavor in Cheddar Cheese. J Dairy Sci 87:1999-2010.

Bordenave-Juchereau SB, Almeida JM, Piot P, Sannier F. 2005. Effect of protein concentration $\mathrm{pH}$ lactose content and pasteurization on thermal gelation of acid caprine whey protein concentrates. J Dairy Res 72(1):34-8.

Boelens M, Van Der Linde LM, de Valois PJ, van Dort HM, Takken HJ. 1974. Organic sulfur compounds from fatty aldehydes, hydrogen sulfide, thiols and ammonia as flavor constituents. J Agric Food Chem 22:1071-6.

Boumerdassi H, Desmazeaud M, Monnet C, Boquein CY, Corrieu G. 1995. Improvement of diacetyl production by Lactococcus lactis ssp. lactis CNRZ 483 through oxygen control. J Dairy Sci 79:775-81.

Bryant C, McClements DJ. 1998. Molecular basis of protein functionality with special consideration of cold-set gels derived from heat denatured whey protein. Food Res Int 33:649-53. Carunchia-Whetstine ME, Parker JD, Drake MA, Larick DK. 2003. Determining flavor and flavor variability in commercially produced liquid cheddar whey. J Dairy Sci 86:439-48.

Carunchia-Whetstine ME, Croissant AE, Drake MA. 2005. Characterization of dried whey protein concentrate and isolate flavor. J Dairy Sci 88:3826-39.

Cervato G, Cazzola R, Cestaro B. 1999. Studies on the antioxidant activity of milk caseins. Int J Food Sci Nutri 50:291-6.

Chen HM, Muramoto K, Yamauchi F. 1995. Structural analysis of antioxidative peptides from soybean $\beta$-conglycinin. J Agric Food Chem 43:574-8.

Chen HM, Muramoto K, Yamauchi F, Nokihara K. 1996. Antioxidant activity of designed peptides based on the antioxidative peptide isolated from digests of a soybean protein. J Agric Food Chem 44:2619-23.

Childs JL, Yates MD, Drake MA. 2007. Sensory properties of meal replacement bars and beverages made from whey and soy proteins. J Food Sci 72:S425-34. 
Childs JL, Drake MA. 2009. Consumer perception of fat reduction in cheese. J Sensory Stud 24:902-21.

Christie WW, Noble RC, Davies G. 1987. Phospholipids in milk and dairy products. Int J Dairy Technol 40:10-2.

Cornish SM, Forbes S, Abeysekara S, Zello GA, Little JP, Candow DG, Jantz NT, Chilibeck PD. 2009. Conjugated linoleic acid combined with creatine monohydrate and whey protein supplementation during strength training. Int J Sport Nutr Exer Metab 19:79-96.

Croissant AE, Kang EJ, Campbell RE, Bastian E, Drake MA. 2009. Impact of bleaching agen on the flavor and flavor chemistry of whey proteins. J Dairy Sci 92:5917-27.

Dave RI, Shah NP. 1997. Effectiveness of ascorbic acid as an oxygen scavenger in improving viability of probiotic bacteria in yoghurts made with commercial starter cultures. Int Dairy J 97:435-43.

de Wit JN. 1998. Nutritional and functional characteristics of whey protein in food products J Dairy Sci 81:597-608.

Diaz M, Decker EA. 2004. Antioxidant mechanisms of caseinophosphopeptides and casein hydrolysates and their application in ground beef. J Agric Food Chem 52:8208-13.

Drake MA. Civille GV. 2003. Flavor lexicons. Crit Rev Food Sci Food Saf 2:33-40.

Drake MA, Karagul-Yuceer Y, Cadwaller KR, Civille GV, Tong PS. 2003. Determination of the sensory attributes of dried milk powders and dairy ingredients. J Sens Stud 18:199-216.

Drake MA. 2006. Flavor and flavor carry-through of whey proteins in beverages. In The wonders of whey... catch the power. Proceedings of the 4th International Whey Conference. Elmhurst, Ill.: American Dairy Products Inst. p 292-300.

Drake MA, Miracle RE, Wright JM. 2009. Sensory properties of dairy proteins. Ch 15 In Thompson A, Boland M, Singh H, editors. Milk proteins: from expression to food. Amster dam, The Netherlands: Elsevier. p 429-48.

Evans J, Zulewska J, Newbold M, Drake MA, Barbano DM. 2009. Comparison of composition, sensory and volatile components of $34 \%$ whey protein and milk serum protein concentrates. J Dairy Sci 92: 4773-91.

Foegeding AE, Davis JP, Doucet D, McGuffey,MK. 2002. Advances in modifying and understanding whey protein functionality. Trends Food Sci Technol 13:151-9.

Forney M. 1974. Formation of hydrocarbons and other volatile products by oxidation of $\mathrm{n}-$ nonanal and n-non-2-enal. Rev Fr Corps Gras 21:429-36.

Fox PF, McSweeney PLH. 1998. Milk lipids. Ch 3 In: Dairy chemistry and biochemistry. 1st ed. New York: Blackie Academic \& Professional. p 67-145.

Frankel EN. 1998. Lipid oxidation. 1st ed. Davis, Calif.: The Oily Press. 232 p.

Gallardo-Escamilla FJ, Kelly AL, Delahunty CM. 2005. Sensory characteristics and related volatile flavor compound profiles of different types of whey. J Dairy Sci 88:2689-99.

Hernandez-Ledesma BA, Dvalos B, Bartolom B, Amigo L. 2005. Preparation of antioxidant enzymatic hydrolysates from $\alpha$-lactalbumin and $\beta$-lactoglobulin. Identification of active peptide by HPLC-MS/MS. J Agric Food Chem 53:588-93.

Javidipour I, Qian MC. 2008. Volatile component change in whey protein concentrate during storage investigated by headspace solid-phase microextraction gas chromatography. Dairy Sci Technol 88:95-104.

Jung MY, Yoon SH, Lee HO, Min DB. 1998. Singlet oyxgen and ascorbic acid effects on dimethyl disulfide and off-flavor in skim milk exposed to light. J Food Sci 63:408-12.

Karagul-Yuceer Y, Drake MA, Cadwallader KR. 2003. Aroma-active components of liquid Cheddar whey. J Food Sci 68:1215-9.

Kirsten WJ, Hesselius GU. 1983. Rapid, automatic, high capacity dumas determination of nitrogen. Microchem J 28:529-47.

Lee YB, Morr CV. 1994. Changes of headspace volatile compounds due to oxidation of milk fat during storage of dried dairy products. In: Ho CT, Hartman TG, editors. Lipids in food flavors. Washington, D.C.: Am Chem Soc. p 98-107.

Lee YB, Laye I, Kim YD, Morr CV. 1995. Formation of volatile compounds in whey protein concentrate during elevated temperature storage as a function of water activity. Int Dair J 6:485-96

Lillard DA, Day EA. 1964. Degradation of monocarbonyls from autoxidizing lipids. J Am Oi Chem Soc 41:549-52.

Lindmark-Månsson H, Åkesson B. 2000. Antioxidative factors in milk. Brit J Nutri 84:S10310.

Mahajan SS, Goddik L, Qian MC. 2004. Aroma compounds in sweet whey powder. J Dairy Sci 87:4057-63

Mahoney JR, Graf E. 1986. Role of alpha-tocopherol, ascorbic acid, citric acid, and EDTA as oxidants in model systems. J Food Sci 51:1293-6.

McIntosh GH, Royle PJ, Lee PK, Leu GO, Regester MA, Johnson RL, Grinsted RS. Kenwar K, Smithers GW. 1998. Whey proteins as functional food ingredients? Int Dairy J 8:42534.

Meilgaard MM, Civille GV, Carr BT. 1999. Sensory evaluation techniques. 3rd ed. Boca Raton, Fla.: CRC Press.
Mills OE, Broome AJ. 1997. Isolation of flavor compounds from protein material. In: Mussinan CJ, Morello MJ, editors. Flavor analysis-developments in isolation and characterization. Washington, D.C.: Am Chem Soc. p 85-91.

Moosman B, Behl C. 2002. Secretory peptide hormones are biochemical antioxidants: structureactivity relationship. Mol Pharmacol 61:260-8.

Morr CV, Ha EYW. 1991. Off-flavors of whey protein concentrates: a literature review. Int Dairy J 1:1-11.

Morr CV, Ha EYW. 1993. Whey protein concentrates and isolates: processing and functional properties. Crit Rev Food Sci Nutri 33:431-76.

Mortenson G, Bertelsen G, Mortensen BK, Stapelfeldt H. 2004. Light-induced changes in packaged cheeses—a review. Int Dairy J 14:85-102.

Mullally MM, Meisel H, FitzGerald RJ. 1997. Angiotensin-I-converting enzyme inhibitory activities of gastric and pancreatic protein digests of whey proteins. Int Dairy J 7:299-303.

Niki E, Saito T, Kawakami A, Kamiya Y. 1984. Inhibition of oxidation of methyl linoleate in solution by vitamin $\mathrm{E}$ and vitamin C. J Biol Chem 259:4177-82.

O'Connor TP, O'Brien NM. 2006. Lipid oxidation. In: Fox PF, McSweeney PLH, editors. Advanced dairy chemistry volume 2 lipids. 3rd ed. London, U.K.: Chapman \& Hall. p 557-600.

Park PJ, Jung WK, Nam KS, Shahidi F, Kim SE. 2001. Purification and characterization of antioxidative peptides from protein hydrolysate of lecithin-free egg yolk. J Am Oil Chem Soc 78:651-6.

Peña-Ramos EA, Xiong YL. 2001. Antioxidant activity of soy protein hydrolysates in a liposomal system. J Food Sci 67:2952-6.

Peña-Ramos EA, Xiong YL. 2003. Whey and soy protein hydrolysates inhibit lipid oxidation in cooked pork patties. Meat Sci 64:259-63.

Pihlanto A. 2006. Antioxidative peptides derived from milk proteins. Int Dairy J 16:1306-14.

Quach ML, Chen XD, Stevenson RJ. 1999. Headspace sampling of whey protein concentrate solutions using solid-phase microextraction. Food Res Int 31:371-9.

Robertson GL, Samaniego CML. 1986. Effect of initial dissolved oxygen levels on the degradation of ascorbic acid and the browning of lemon juice during storage. J Food Sci 51:184-8.

Rombaut R, Dewettinck K. 2006. Properties, analysis, and purification of milk polar lipids. Int Dairy J 16:1362-73.

Rombaut R, Dewettinck K, van Camp J. 2007. Phospho- and sphingolipid content of selected dairy products as determined by HPLC coupled to an evaporative light scattering detector (HPLC-ELSD). J Food Comp Anal 20:308-12.

Russell TA, Drake MA, Gerard PD. 2006. Sensory properties of whey and soy proteins. J Food Sci 71:447-55.

Saguy I, Kopelman IJ, Mizrahi S. 1978. Simulation of ascorbic acid stability during heat processing and concentration of grapefruit juice. J Food Proc Engr 2:213-25.

Schieberle P, Grosch W. 1981. Model experiments about the formation of volatile carbonyl compounds. J Am Oil Chem Soc 58:602-7.

Stevenson RJ, Chen XD. 1996. A study of volatile "trapping" in spray dried whey protein concentrate by "crushing" and/or vacuuming, and detection by solid-phase microextraction/gas chromatography/mass spectrometry. Food Res Int 29:495-504.

Suetsana K, Ukeda H, Ochi H. 2000. Isolation and characterization of free radical scavenging activities peptides derived from casein. J Nutri Biochem 11:128-31

Suriyaphan O, Drake MA, Cadwallader KR. 2001. Lipid oxidation of deoiled soy lecithin by lactic acid bacteria. Lebens Wiss Technol 34:462-8.

Tomaino RM, Parker JD, Larick DK. 2001. Analysis of free fatty acids in whey products by solid-phase microextraction. J Agric Food Chem 49:3993-8.

Tomaino RM, Turner LG, Larick DK. 2004. The effect of Lactococcus lactis starter cultures on the oxidative stability of liquid whey. J Dairy Sci 87:300-7.

Tong LM, Sasaki S, McClements DJ, Decker EA. 2000. Mechanisms of the antioxidant activity of a high molecular weight fraction of whey. J Agric Food Chem 48:1473-8.

Van Den Dool H, Kratz PD. 1963. A generalization of the retention index system including linear temperature programmed gas-liquid partition chromatography. J Chrom 11:463-7.

Villota R, Karel M. 1980. Prediction of ascorbic acid retention during drying II. simulation of retention in a model system. J Food Proc Pres 4:141-59.

Wong PYY, Kitts DD. 2003. Chemistry of buttermilk solid antioxidant activity. J Dairy Sci $86: 1541-7$

Wright BJ, Zevchak SE, Wright JM, Drake MA. 2009. The impact of agglomeration and storage on flavor and flavor stability of whey protein $80 \%$ and whey protein isolate. J Food Sci 74:S17-29.

Wright JM, Carunchia-Whetstine ME, Miracle RE, Drake MA. 2006. Characterization of a cabbage off-flavor in whey protein isolate. J Food Sci 71:86-90.

Yamashoji S, Kajimoto G. 1980. Antioxidant effect of Gly-Gly-His on Cu(II)-catalyzed autoxidation and photosensitized oxidation of lipids. Agric Biol Chem 44:2735-6. 